\title{
AKSES DAN DAMPAK KREDIT MIKRO TERHADAP PRODUKSI PADI ORGANIK DI KABUPATEN BOGOR
}

\author{
Dewi Rohma Wati ${ }^{1}$, Nunung Nuryartono ${ }^{2}$, Lukytawati Anggraeni ${ }^{2}$ \\ ${ }^{1}$ Mahasiswa Magister Program Studi Ilmu Ekonomi Pertanian, FEM IPB \\ ${ }^{2}$ Staf Pengajar FEM IPB
}

Artikel diterima September 2014

Artikel disetujui untuk dipublikasikan Desember 2014

\begin{abstract}
The ultimate problem of organic paddy farm is limited access formal credit due to collateral requirement. Farmers only have access to semi-formal institution like cooperatives and group of farmers (Gapoktan.red) because of simplicity of administration procedure and payment system. The objectives of this study are to analized accessibility of micro-credit to organic paddy farmers in Bogor and its impact to production of organic paddy. With Heckman Sample Selection Model, we found that access of credit influenced negatively by age of farmers, number of household member, membership of farm group, and the acreage of land use. Microcredit give significant impact to production of organic paddy and it is simultaneous with fertilizer and labor. Microcredit that they have taken used to pay labor and also bought the fertilizer.
\end{abstract}

Keywords : access of microcredit, impact of microcredit, production of organic paddy

\section{PENDAHULUAN}

Penyaluran kredit dari bank umum untuk sektor pertanian di Indonesia masih tersegmentasi pada usahatani besar dan menengah. Pada bank umum, sektor pertanian hanya memperoleh sebesar 7,4 persen dari total kredit yang disalurkan sedangkan pada Bank Pembiayaan Rakyat (BPR) sebesar 17,6 persen (BSBI 2013). Sangat berbeda dengan sektor perdagangan yang memiliki pangsa terbesar kredit bank umum dan BPR yaitu 27,75 persen dan 64,30 persen (Tabel 1). Alasan utama bagi perbankan formal tidak memberikan kredit kepada petani adalah karena faktor ketidakpastian dan rentang waktu (time lag) dalam proses produksi (Anggraeni 2009) yang tidak memungkinkan petani membayar kredit dengan mekanisme biasa. Selain itu adanya track record buruk pada saat banyak digulirkan kredit program pemerintah yang akhirnya diputihkan tanpa meminta pertanggungjawaban petani (Hanafie 2010).

Namun demikian, petani tidak hanya dihadapi pada persoalan akses kredit. Kualitas komoditi pertanian, khususnya pangan menjadi sorotan dunia terkait keamanan dan keberlanjutannya. Slogan back to nature menjadi tren di masyarakat dan diwujudkan melalui perdagangan global yang mensyaratkan keamanan, bernutrisi tinggi, dan ramah lingkungan 
(Gultom 2014). Hal ini dikarenakan semakin menurunnya tingkat kesuburan lahan pertanian dan ketergantungan terhadap penggunaan pupuk dan obat- obatan kimia tanpa diimbangi dengan recovery lahan menggunakan bahanbahan organik (Kusmulyono et al 2007).

Tabel 1 Distribusi kredit antar sektor dari Bank Umum dan BPR tahun 2012-2013

\begin{tabular}{|c|c|c|c|c|}
\hline \multirow[b]{2}{*}{ Sektor } & \multicolumn{2}{|c|}{ Bank Umum } & \multicolumn{2}{|c|}{ BPR } \\
\hline & $\begin{array}{c}\text { Pangsa } \\
(\%)\end{array}$ & $\begin{array}{c}\text { Suku Bunga } \\
(\%)\end{array}$ & $\begin{array}{l}\text { Pangsa } \\
(\%)\end{array}$ & $\begin{array}{c}\text { Suku } \\
\text { Bunga }(\%)\end{array}$ \\
\hline Pertanian, perikanan, perburuan, dan kehutanan & 7,40 & 11,6 & 17,60 & 33,58 \\
\hline Perikanan & 0,27 & 13,31 & 0,52 & 30,69 \\
\hline Pertambangan dan penggalian & 4,85 & 12,07 & 0,47 & 28,24 \\
\hline Industri pengolahan & 23,80 & 10,73 & 3,13 & 28,22 \\
\hline Listrik, gas, dan air & 3,26 & 9,00 & 0,15 & 28,56 \\
\hline Konstruksi & 5,22 & 11,86 & 5,66 & 29,56 \\
\hline Perdagangan besar dan eceran & 27,75 & 12,99 & 64,30 & 29,47 \\
\hline Penyediaan akomodasi & 2,49 & 12,28 & 1,58 & 29,32 \\
\hline Transportasi pergudangan & 6,78 & 10,82 & 4,83 & 27,36 \\
\hline Perantara keuangan & 6,47 & 10,13 & 0,34 & 22,26 \\
\hline $\begin{array}{l}\text { Real estate, usaha persewaan, dan jasa } \\
\text { perusahaan }\end{array}$ & 8,32 & 12,36 & 2,14 & 23,20 \\
\hline Administrasi pemerintahan & 0,27 & 11,95 & 0,39 & 26,06 \\
\hline Jasa Pendidikan & 0,23 & 13,44 & 0,59 & 28,81 \\
\hline Jasa kesehatan dan kegiatan sosial & 0,42 & 12,33 & 0,44 & 29,37 \\
\hline Jasa kemasyarakatan & 2,30 & 13,20 & 9,84 & 27,69 \\
\hline Jasa perorangan & 0,06 & 14,83 & 2,77 & 29,75 \\
\hline Badan internasional & 0,01 & 9,70 & 12,78 & 29,38 \\
\hline Kegiatan yang belum jelas batasannya & 0,10 & 10,83 & 13,85 & 24,59 \\
\hline SB Dep rata-rata & & 6,99 & & 9,03 \\
\hline
\end{tabular}

Pembangunan sektor pertanian diarahkan pada pembangunan berkelanjutan dimana petani harus mengubah pola pikir tentang pentingnya menjaga kesuburan lahan pertaniannya. Hal tersebut didukung dengan maraknya kampanye mengenai green agriculture for sustainable development untuk mengurangi penggunaan bahan-bahan kimia dalam proses produksi pertanian. Input-input tersebut selain dapat merusak tanah, dalam jangka panjang dapat meningkatkan pertumbuhan penyakit di dalam tubuh manusia. Selain itu juga pemerintah telah mencanangkan pertanian organik dengan jargon Go Organic 2010 (Ditjen BPPHP Kementan 2010).
Kabupaten Bogor, secara regional berada di Provinsi Jawa Barat, masih menjadikan pertanian sebagai sektor unggulan walaupun pangsa terhadap PDRB hanya 12,6 persen (BPS Provinsi Jawa Barat 2013). Subsektor tanaman pangan yakni padi merupakan komoditas yang banyak diusahakan namun petani padi di Kabupaten Bogor masih tergolong miskin (BPS Kabupaten Bogor 2013). Hal ini dikarenakan sulitnya memperoleh bantuan modal untuk meningkatkan usahatani. Akses petani terhadap lembaga keuangan formal masih rendah. Petani menghadapi kendala teknis terkait collateral dan proses administrasi yang rumit dan memakan biaya, sehingga petani mencari 
alternatif sumber pembiayaan pada lembaga keuangan non-formal (Nizar 2004; Paloma 2013; Azriani 2014). Di Kabupaten Bogor distribusi kredit dari lembaga formal untuk petani masih sangat kecil, yakni hanya 6,2 persen saja dari total kredit yang disalurkan (Tabel 2). Menurut jenis usaha, yaitu kecil dan mikro, sektor pertanian di
Kabupaten Bogor sebagian besar berada pada jenis ini. Pada tahun 2012, usaha kecil dan mikro masing-masing hanya memperoleh kredit 27,84 persen dan 14,05 persen dari total kredit yang disalurkan. Nilai ini masih sangat potensial untuk ditingkatkan terutama bagi sektor pertanian.

Tabel 2 Perkembangan Posisi Kredit Bank Umum di Indonesia dan Kabupaten Bogor Tahun $2010-2012$

\begin{tabular}{|c|c|c|c|c|c|}
\hline $\begin{array}{l}\text { Posisi Kredit Menurut } \\
\text { Lapangan Usaha }\end{array}$ & $\begin{array}{l}2010 \\
\text { (Miliar } \\
\text { Rp) }\end{array}$ & $\begin{array}{l}2011 \\
\text { (Miliar } \\
\text { Rp) }\end{array}$ & $\begin{array}{l}2012 \\
\text { (Miliar } \\
\text { Rp) }\end{array}$ & $\begin{array}{c}\text { Pangsa } \\
\text { Sektor di } \\
\text { Indonesia } \\
\text { tahun } \\
2012(\%)\end{array}$ & $\begin{array}{c}\text { Pangsa } \\
\text { Sektor di } \\
\text { Kab. Bogor } \\
\text { tahun } 2012 \\
(\%)\end{array}$ \\
\hline $\begin{array}{l}\text { Total Kredit Secara } \\
\text { Umum }\end{array}$ & 17.095 .153 & 21.675 .652 & 26.679 .991 & - & - \\
\hline $\begin{array}{l}\text { Pertanian, peternakan, } \\
\text { kehutanan, dan } \\
\text { perikanan }\end{array}$ & 121.387 & $188 . .201$ & 281.499 & 8,23 & 6,20 \\
\hline $\begin{array}{l}\text { Pertambangan dan } \\
\text { penggalian }\end{array}$ & 44.841 & 19.327 & 22.340 & 0,89 & 0,49 \\
\hline Industri Pengolahan & 1.176 .075 & 940.572 & 1.186 .403 & 9,82 & 26,11 \\
\hline $\begin{array}{l}\text { Listrik, gas, dan air } \\
\text { bersih }\end{array}$ & 9.409 & 13.782 & 7.889 & 0,28 & 0,17 \\
\hline Konstruksi & 950.035 & 321.542 & 439.738 & 6,71 & 9,68 \\
\hline $\begin{array}{l}\text { Perdagangan, hotel, dan } \\
\text { restoran }\end{array}$ & 1.205 .337 & 1.420 .776 & 1.796 .947 & 55,95 & 39,55 \\
\hline $\begin{array}{l}\text { Pengangkutan dan } \\
\text { komunikasi }\end{array}$ & 59.311 & 65.128 & 72.828 & 3,95 & 1,60 \\
\hline $\begin{array}{l}\text { Keuangan, real estate, } \\
\text { dan jasa perusahaan }\end{array}$ & 211.139 & 220.667 & 246.306 & 7,6 & 5,42 \\
\hline Jasa-jasa & 211.139 & 526.452 & 489.467 & 6,58 & 10,77 \\
\hline
\end{tabular}

Kabupaten Bogor menjadi salah satu dari 20 kabupaten yang dijadikan sentra penanaman produk organik yang menjadi program pemerintah sejak tahun 2000 (Saragih 2010). Terdapat 11 kecamatan yang berpotensi untuk menjadi sentra produksi padi organik. Untuk itu Pemerintah Kabupatan Bogor sangat mendukung adanya pengembagan padi organik ini dan berupaya untuk meningkatkan produksi beras organik. Demi menunjang program tersebut, dibutuhkan dukungan modal sebagai insentif usahadalam pengembangan usahatani padi organik ini. Petani padi organik di Kabupaten Bogor belum mendapatkan kredit dari lembaga keuangan formal karena ratarata skala usahatani yang sangat kecil, yakni tidak lebih dari 0,5 Ha. Sehingga untuk meningkatkan produksi dibutuhkan tambahan modal berupa kredit lunak tanpa agunan (collateral). 
Berdasarkan latar belakang dan permasalahan yang ada, maka tujuan dari penelitian ini, yaitu : (1) menganalisis aksesibilitas kredit mikro pada petani padi organik di Kabupaten Bogor dan (2) menganalisis dampak kredit mikro terhadap produksi padi organik di Kabupaten Bogor.

\section{METODE}

\section{Lokasi dan Waktu Penelitian}

Penelitian dilakukan di Kabupaten Bogor dan secara purposive memilih 3 desa dari 3 kecamatan yang telah menerapkan sistem pertanian organik. Penelitian ini dilaksanakan pada bulan Juni sampai Agustus 2014.

\section{Metode Pengambilan Sampel}

Pemilihan lokasi sampel dilakukan secara sengaja (purposive) dan responden dipilih secara acak (random) berdasarkan kriteria yang sesuai dengan kebutuhan penelitian. Sebanyak 68 petani menjadi responden dengan kriteria penerima kredit sebanyak 35 petani dan 33 petani bukan penerima kredit. lokasi petani masingmasing di Desa Cibalung (Kecamatan Cijeruk), Desa Muara Jaya (Kecamatan Caringin), dan Desa Ciburuy (Kecamatan Cigombong).

\section{Analisis Data}

Untuk menjawab tujuan dari penelitian ini digunakan Heckman Selection Model (Heckman 1976; Hopkins 2005; Ibrahim dan Bauer 2013). Model ini terdiri dari dua langkah yang terdiri dari dua persamaan yaitu outcome equation dan selection equation. Langkah pertama menggunakan model Probit (selection equation) yang bertujuan untuk mengidentifikasi faktor-faktor yang mempengaruhi petani mengakses kredit mikro. Sedangkan langkah kedua (outcome equation) ditempuh untuk menjawab tujuan kedua dan ketiga yakni melihat dampak yang ditimbulkan dari adanya kredit mikro tersebut terhadap produksi padi organik dan pendapatan usahatani. Model Seleksi Heckman ini memperbolehkan penggunaan informasi dari persamaan seleksi pada tahap pertama yang diestimasi dengan menggunakan metode estimasi Likelihood maksimum (Ibrahim dan Bauer, 2013). Model ini lebih konsisten, estimasi efisien secara asimtotik untuk semua parameter dalam model.

Untuk melihat kesesuaian model seleksi Heckman dilakukan uji statistik secara serentak dan parsial. Uji statistik secara serentak menggunakan uji $\mathrm{G}^{2}$ atau likelihood ratio test. Untuk uji statistik secara parsial menggunakan uji Wald yang mengikuti distribusi normal strandar, maka pengujian dilakukan dengan membandingkan statistik uji Wald dengan distribusi normal standar pada taraf nyata 0,05 . Ditolak $\mathrm{H}_{0}$ jika nilai mutlak $\mathrm{W}>\mathrm{Z}_{\mathrm{a} / 2}$ atau $\mathrm{p}$-value < taraf nyata.

\section{Analisis Akses Kredit Mikro Petani Padi organik}

Peluang akses terhadap kredit mikro merupakan suatu keputusan yang bersifat kualitatif yaitu akses atau tidak akses. Sehingga model untuk mengidentifikasi akses kredit mikro di Kabupaten Bogor menggunakan model Probit yang merupakan tahap pertama dari Model Seleksi Heckman lalu diestimasi menggunakan metode maksimum likelihood secara keseluruhan dan uji Wald secara parsial. Model ini membolehkan penggunaan informasi dari sampel petani yang bukan penerima kredit untuk mengembangkan estimasi dalam model regresi di tahap kedua (Ibrahim dan 
Bauer 2013). Untuk mengidentifikasi faktor-faktor apa saja yang mempengaruhi petani padi organik memperoleh akses atau tidak pada kredit mikro, maka dibuatlah persamaan seleksi dalam bentuk regresi probit. Variabel-variabel yang digunakan adalah variabel yang juga digunakan pada beberapa studi terdahulu mengenai akses kredit oleh Ibrahim dan Bauer (2013) sebagai berikut :

$$
\begin{aligned}
& Z^{*}=\alpha_{0}+\alpha_{1} w_{1}+\alpha_{2} w_{2}+\alpha_{3} w_{3}+ \\
& \alpha_{4} w_{4}+\alpha_{5} w_{5}+\alpha_{6} w_{6}+\varepsilon_{i} \ldots
\end{aligned}
$$

Dimana :

$$
\begin{aligned}
\mathrm{Z}= & \text { Peluang akses terhadap kredit } \\
& \text { mikro }(1=\text { akses; } 0=\text { tidak } \\
& \text { akses) } \\
\alpha_{\mathrm{i}}= & \text { parameter estimasi } \\
w_{1}= & \text { usia petani (tahun) } \\
w_{2}= & \text { jumlah anggota keluarga (orang) } \\
w_{3}= & \text { lama pendidikan petani (tahun) } \\
w_{4}= & \text { pengalaman usahatani (tahun) } \\
w_{5}= & \text { lama keanggotaan kelompok tani } \\
& \text { (tahun) } \\
w_{6}= & \text { luas lahan garapan (ha) } \\
\varepsilon_{\mathrm{i}}= & \text { variabel acak }
\end{aligned}
$$

Tanda parameter yang diharapkan adalah $\alpha_{1}, \alpha_{2}, \alpha_{3}, \alpha_{4}, \alpha_{5}, \alpha_{6}>0$.

\section{Analisis Dampak Kredit terhadap Produksi Padi organik}

Untuk menjawab tujuan kedua yakni dampak kredit mikro terhadap produksi padi organik, digunakan model regresi linier yang merupakan tahap kedua dari Model Seleksi Heckman (Heckman 1976; Hopkins 2005; Ibrahim dan Bauer 2013) dan diestimasi menggunakan metode maksimum likelihood dan uji Wald. Model regresi pada tahap kedua ini adalah outcome equation dimana hasil seleksi dari model di tahap pertama akan dilihat dampak dari adanya kredit mikro terhadap produksi padi organik.

Produksi padi organik dapat ditentukan oleh faktor-faktor teknis maupun non-teknis. Dalam penelitian ini, produksi padi organik ditentukan oleh faktor-faktor teknis dimana dilibatkan penggunaan input sebagai variabel bebas yang dapat mempengaruhi produksi padi organik. Adapun faktor-faktor tersebut dimasukkan dalam sebuah persamaan hasil yang merupakan tahap kedua dari Model Seleksi Heckman, yaitu :

$\mathrm{Y}=\beta_{0}+\beta_{1} \mathrm{x}_{1}+\beta_{2} \mathrm{x}_{2}+\beta_{3} \mathrm{x}_{3}+\beta_{4} \mathrm{x}_{4}+$ $\beta_{5} \mathrm{X}_{5}+\mathrm{u}$

Dimana :

$\mathrm{Y}=\operatorname{produksi}$ padi $(\mathrm{Kg})$

$\mathrm{x}_{1}=$ jumlah penggunaan benih $(\mathrm{Kg})$

$\mathrm{x}_{2}=$ jumlah penggunaan pupuk organik $(\mathrm{Kg})$

$\mathrm{x}_{3}=$ jumlah penggunaan pupuk kimia $(\mathrm{Kg})$

$\mathrm{x}_{4}=$ jumlah tenaga kerja (HKP)

$\mathrm{x}_{5}=$ jumlah kredit yang diterima petani ( $\mathrm{Rp}$ )

$\beta_{0}=$ konstanta

$\beta_{\mathrm{i}}=$ parameter estimasi

$\mathrm{u}_{1}=$ variabel acak

Tanda parameter yang diharapkan adalah : $\beta_{1}, \beta_{2}, \beta_{3}, \beta_{4}, \beta_{5}>0$ dan $<0$.

\section{Definisi Operasional}

1. Usia petani adalah usia petani responden pada saat penelitian dilakukan dengan satuan tahun.

2. Pendidikan petani diukur dari lamanya pendidikan formal yang ditempuh petani dengan satuan yang digunakan adalah tahun.

3. Jumlah anggota keluarga adalah banyaknya anggota keluarga yang masih dibiayai oleh petani responden dengan satuan yang 
digunakan adalah banyaknya orang.

4. Pengalaman usahatani adalah lamanya petani melakukan usahatani baik itu padi organik maupun pengalaman-pengalaman usahatani sebelumnya dengan satuan yang digunakan adalah tahun.

5. Lama keanggotaan kelompok tani adalah lamanya petani menjadi anggota kelompok tani dan satuan yang digunakan adalah tahun.

6. Luas lahan garapan adalah luasan lahan yang digarap petani padi organik untuk satu musim tanam dan satuan yang digunakan adalah meter persegi.

7. Jumlah benih adalah banyaknya benih yang digunakan untuk 1 musim tanam padi dengan satuan kilogram.

8. Jumlah pupuk organik adalah jumlah pupuk kandang dan pupuk kompos yang digunakan selama 1 musim tanam dengan satuan kilogram.

9. Jumlah pupuk kimia adalah penjumlahan pupuk kimia (Urea, TSP, ZA, dan atau $\mathrm{KCl}$ ) yang digunakan selama 1 musim tanam dengan satuan kilogram.

10. Jumlah tenaga kerja adalah tenaga kerja yang digunakan dalam usahatani padi organik selama 1 musim tanam dan dikonversi ke dalam satuan jam kerja pria (JKP) dimana perbandingan untuk tenaga kerja wanita adalah 1:0,8 dan untuk traktor per 1 hari penggunaan setara dengan 5 HKP.

11. Jumlah kredit adalah sejumlah uang yang dipinjam oleh petani untuk meningkatkan modal usahatani padi organik pada satu musim tanam dengan satuan yang digunakan adalah rupiah (Rp).
12. Produksi padi organik merupakan hasil panen 1 musim tanam dalam bentuk gabah kering panen (GKP) dalam satuan kilogram.

\section{HASIL DAN PEMBAHASAN Pertanian Padi organik di Kabupaten Bogor}

Sistem pertanian organik di Kabupaten Bogor dimulai pada tahun 2004 atas prakarsa dari 3 pihak terkait yaitu petani, dinas pertanian Kabupaten Bogor, dan Dompet Dhuafa. Kerjasama ketiganya menjaring beberapa kelompok tani untuk menerapkan sistem pertanian sehat dengan mengurangi penggunaan pupuk kimia secara bertahap serta meninggalkan penggunaan pembasmi hama dari bahan-bahan kimia. Sistem usahatani seperti ini biasa disebut dengan LEISA (low external input sustainable agriculture).

Petani yang bergabung dengan kelompok tani, difasilitasi oleh Dinas Pertanian berupa penyediaan input seperti benih, pupuk, dan traktor tangan. Sedangkan pihak Dompet Dhuafa melakukan penyuluhan dan pelatihan mengenai sistem pertanian organik itu sendiri serta membukakan pasar untuk memasarkan hasil panen dari petani. Sistem pertanian organik ini dilakukan secara bertahap dengan mengurangi penggunaan pupuk kimia sebesar $25 \%$. Pada setiap tahun dikurangi sebanyak $25 \%$ sampai saat ini sudah ada petani yang konsisten meninggalkan pupuk kimia, tapi masih ada petani yang menggunakan sedikit pupuk kimia untuk merangsang pertumbuhan tanaman.

\section{Karakteristik Responden}

Analisis akses dan dampak kredit mikro terhadap produksi dan penerimaan usahatani padi organik, dihitung menggunakan perangkat lunak 
STATA 13.0 dan dilakukan dalam dua tahap. Dikarenakan model seleksi Heckman membolehkan memasukkan responden kontrol sebagai pembanding, maka penghitungan menggunakan STATA hanya dilakukan dua kali. Sebagai gambaran awal, dilakukan penghitungan secara deskriptif untuk Berdasarkan hasil penghitungan secara deskriptif, dapat dilihat bahwa data pada setiap variabel memiliki keragaman yang cukup tinggi. Hal ini dibuktikan dengan nilai deviasi standar yang positif Sehingga data yang dimasukkan dapat mewakili keseluruhan populasi yang ada, yaitu petani padi organik di Kabupaten Bogor.

Usia petani rata-rata 51 dan 54 tahun untuk petani penerima kredit dan bukan penerima kredit. Hal ini menandakan bahwa usahatani padi melihat keragaman data yang digunakan untuk masing-masing variabel. Tabel 2 menyajikan hasil penghitungan deskriptif variabel-variabel dalam model yang dibagi menjadi dua kategori berdasarkan status akses dan tidak akses pada kredit mikro.

organik didominasi orang-orang tua yang tidak memiliki keahlian lain karena tingkat pendidikan yang rendah, yaitu rata-rata hanya mampu menyelesaikan sekolah dasar dan tidak sampai menamatkan sekolah menengah pertama baik petani penerima kredit maupun petani yang tidak mengakses kredit. Petani memperoleh ilmu mengenai usahatani padi secara turun temurun dari orang tua dan tidak diperoleh dari pendidikan formal.

Tabel 3 Karakteristik responden

\begin{tabular}{lcrr}
\hline \multicolumn{1}{c}{ Variabel } & Jml Responden & Rata-rata & Deviasi standar \\
\hline & Petani tidak akses kredit & & \\
Usia petani (tahun) & 33 & 54,15 & 10,49 \\
Jumlah anggota keluarga (orang) & 33 & 3,58 & 2,41 \\
Lama pendidikan petani (tahun) & 33 & 8,36 & 2,69 \\
Pengalaman usahatani (tahun) & 33 & 18,15 & 8,51 \\
Lama jadi anggota kel.tani (tahun) & 33 & 6,94 & 2,47 \\
Luas lahan garapan (ha) & 33 & 0,26 & 0,23 \\
Produksi GKP (Ton) & 33 & 1,58 & 1,64 \\
Produktifitas (ton/ha) & 33 & 5,58 & 1,34 \\
\hline & & & \\
Usia petani (tahun) & Petani akses kredit & 51,3 & 11,95 \\
Jumlah anggota keluarga (orang) & 35 & 2,69 & 1,75 \\
Lama pendidikan petani (tahun) & 35 & 8,26 & 2,64 \\
Pengalaman usahatani (tahun) & 35 & 16,0 & 10,54 \\
Lama jadi anggota kel.tani (tahun) & 35 & 7,60 & 2,19 \\
Luas lahan garapan (ha) & 35 & 0,38 & 0,24 \\
Produksi GKP (Ton) & 35 & 1,86 & 1,19 \\
Produktifitas (ton/ha) & 35 & 5,04 & 1,28 \\
Jumlah kredit (Rp) & 35 & 778 & 430 \\
\hline Sumber: Data primer & 35 & &
\end{tabular}

Sumber : Data primer

Jumlah anggota keluarga petani penerima kredit sebanyak 3 orang dan petani bukan penerima kredit sebanyak 4 orang. Hal ini bukan berarti petani tidak memiliki banyak anak, namun karena usia petani sudah setengah baya maka sebagian bahkan semua anak dari petani sudah memiliki keluarga. Sehingga petani tidak lagi memiliki tanggungan keluarga yang banyak. 
Justru hal ini menguntungkan petani karena dapat membantu dalam permodalan usahatani bagi mereka yang memiliki penghasilan lebih. Kondisi ini juga dapat meningkatkan kelayakan (credit worthiness) petani untuk mengakses kredit.

Pengalaman usahatani petani ratarata lebih dari 18 tahun sehingga dapat dikatakan bahwa kemampuan petani sudah dapat mengelola usahatani dengan baik khususnya dalam penggunaan input dan mengetahui fenomena-fenomena alam yang mungkin terjadi selama musim tanam. Berdasarkan pengalaman juga, petani lebih memahami kondisi lahan dan apa yang dibutuhkan tanaman selama proses tanam sampai panen. Hal ini menjadi penting mengingat sektor pertanian adalah sektor yang memiliki risiko relatif tinggi karena tergantung pada kondisi alam di luar usaha yang telah dilakukan oleh petani itu sendiri. Namun demikian, petani padi organik masih tergolong petani yang risk averse, sehingga tidak banyak mengeksplor semua sumber daya yang dimiliki dan mungkin diperoleh (Rahayu 2011).

Variabel penting yang juga harus dimiliki oleh petani adalah keanggotaan dalam suatu kelompok tani. Dimana akan menjadi modal sosial bagi petani untuk bisa memanfaatkan segala informasi dan jaringan yang dapat diakses melalui kelompok tani. Termasuk juga informasi mengenai akses terhadap permodalan. Baik dari lembaga formal maupun semi-formal. Keikutsertaan petani dalam kelompok tani akan membangun imej bagi anggota lain dan juga kepercayaan lembaga penyalur kredit agar dapat mengakses kredit sejumlah yang dibutuhkan.

Pada luas lahan garapan, dapat dilihat bahwa petani penerima kredit memiliki luas lahan garapan lebih besar dari petani bukan penerima kredit. Petani yang tidak memperoleh kredit hanya mengusahakan lahan rata-rata 0,26 hektar sedangkan petani penerima kredit, rata-rata luas lahan yang digarap seluas 0,38 hektar. Walau demikian luas lahan yang demikian masih sangat kecil jika ingin mencapai produktifitas yang optimal dan pendapatan yang besar pula.

\section{Input dan Output Usahatani Padi organik}

Penggunaan input untuk produksi padi organik tidak jauh berbeda dengan padi konvensional. Hanya terjadi pengurangan dalam penggunaan pupuk kimia tapi diperbanyak penggunaan pupuk organik. Pupuk organik yang digunakan adalah jerami yang didiamkan selama 2-4 minggu bersamaan juga dengan kotoran ternak sehingga membusuk dan menjadi kompos. Lalu kompos tersebut dimasukkan kembali ke lahan sambil dilakukan pembajakan tanah. Jika dihitung dari total jerami hasil panen per satuan hektar tanah, maka diperkirakan menghasilkan 12 ton kompos jerami. Namun tidak semua petani memanfaatkan jerami tersebut secara keseluruhan. Dari hasil wawancara dengan petani, jerami yang digunakan tidak sampai 12 ton per hektar. Seperti yang terlihat pada tabel di bawah ini. Penggunaan pupuk organik paling banyak hanya mencapai 7,79 ton (Tabel 4).

Padi organik yang dimaksud dalam penelitian ini belum sepenuhnya murni menggunakan pupuk organik saja. Tapi masih menggunakan pupuk kimia untuk membantu perangsangan pertumbuhan tanaman padi dengan dosis rendah, karena petani masih menerapkan sistem tanam LEISA (Low External Input Sustainable Agriculture) atau petani setempat menyebutnya pertanian organik rasional. Penggunaan 
pupuk kimia, tidak semua petani menggunakan kombinasi pupuk dan dosis yang sama. Setelah dilakukan penghitungan rata-rata, petani menggunakan pupuk jenis urea, TSP, $\mathrm{KCl}$, dan Ponska. Adapun pupuk kimia yang paling banyak digunakan adalah urea dengan rata-rata penggunaan per hektar adalah $53 \mathrm{~kg}$ dan $62 \mathrm{~kg}$ untuk masing-masing petani penerima kredit dan non-kredit.

Padi organik yang dimaksud dalam penelitian ini belum sepenuhnya murni menggunakan pupuk organik saja. Tapi masih menggunakan pupuk kimia untuk membantu perangsangan pertumbuhan tanaman padi dengan dosis rendah, karena petani masih menerapkan sistem tanam LEISA (Low External Input Sustainable Agriculture) atau petani setempat menyebutnya pertanian organik rasional. Penggunaan pupuk kimia, tidak semua petani menggunakan kombinasi pupuk dan dosis yang sama. Setelah dilakukan penghitungan rata-rata, petani menggunakan pupuk jenis urea, TSP, $\mathrm{KCl}$, dan Ponska. Adapun pupuk kimia yang paling banyak digunakan adalah urea dengan rata-rata penggunaan per hektar adalah $53 \mathrm{~kg}$ dan $62 \mathrm{~kg}$ untuk masing-masing petani penerima kredit dan non-kredit.

Tabel 4 Input dan output usahatani padi organik per hektar per satu musim tanam

\begin{tabular}{lrr}
\hline \multicolumn{1}{c}{ Input-output } & Petani penerima kredit & Petani non-kredit \\
\hline Input : & 30 & 37 \\
Benih (Kg/ha) & 6.110 & 7.790 \\
Pupuk organik (Kg/Ha) & 53 & 62 \\
Pupuk Urea (Kg/Ha) & 21 & 21 \\
Pupuk TSP (Kg/Ha) & 3 & 9 \\
Pupuk KCl (Kg/Ha) & 3 & 19 \\
Pupuk Ponska (Kg/Ha) & 26 & 40 \\
Tenaga kerja dalam keluarga (HKP) & 137 & 126 \\
Tenaga kerja luar keluarga (HKP) & & \\
\hline Output : & 4,77 & 5,52 \\
GKP (Ton) & & \\
Sumber : Data primer & & \\
Keterangan : & & \\
- Tenaga kerja dalam keluarga & $=$ tenaga kerja wanita + tenaga kerja pria \\
- Tenaga kerja luar keluarga & $=$ tenaga kerja wanita + tenaga kerja pria + tenaga mesin traktor
\end{tabular}

Selain itu penggunaan benih juga masih tinggi dikarenakan petani masih harus menyulam tanaman sampai beberapa kali. Normalnya untuk satu hektar lahan, dibutuhkan benih sebanyak $25 \mathrm{~kg}$. Hal ini dilakukan karena banyaknya hama yang memakan tanaman padi yang masih muda seperti tikus, penggerek batang, dan keong mas. Rata-rata penggunaan benih adalah $30 \mathrm{~kg}$ dan $37 \mathrm{~kg}$ pada masing-masing petani penerima kredit dan non-kredit. Benih yang digunakan tidak sama varietasnya, tergantung dari musim dan kemungkinan serangan hama yang ada. Di antara varietas benih yang digunakan, yaitu : situ bagendit, inpari, sidenok, sintanur, ciherang, mekonga, dan IR 64. Semua benih tersebut merupakan rekomendasi pemerintah untuk digunakan oleh petani baik dengan sistem organik maupun konvensional.

Penggunaan tenaga kerja pada petani non-kredit jumlahnya lebih banyak dibandingkan dengan petani penerima kredit. Tenaga kerja yang dimaksud adalah gabungan dari tenaga 
kerja pria, wanita, dan mesin (traktor). Masing-masing memiliki peranan tersendiri dalam pelaksanaan teknis usahatani. Tenaga kerja pria lebih diutamakan untuk mengolah lahan, pengolahan jerami untuk kompos, dan melakukan pekerjaan berat seperti pengangkutan hasil panen. Tenaga kerja wanita dibutuhkan pada saat proses penanaman, penyiangan, dan panen karena tidak membutuhkan banyak tenaga hanya ketelitian dan kerapihan dalam menyusun tanaman menurut jarak tanam yang telah ditentukan. Tenaga kerja mesin digunakan untuk membajak sawah supaya lebih menghemat waktu dan biaya karena lebih cepat dan hasilnya lebih baik. Adapun perbandingan penggunaan tenaga kerja pada usahatani penerima kredit yaitu 2,8:4,1:3,1 dan usahatani non-kredit yaitu $2,7: 4,8: 2,5$ untuk masing tenaga kerja wanita, pria, dan mesin.

Proses pembasmian hama atau penyakit tidak dilakukan dengan pestisida atau obat-obatan kimia sejak pertama kali beralih ke sistem pertanian organik. Dengan demikian petani dapat mengurangi biaya untuk membeli obatobatan dan dialihkan untuk membeli atau membuat pupuk organik. Namun demikian petani tetap berusaha mengurangi hama dengan menghadirkan musuh alami hama tersebut atau membuat perangkap agar hama-hama tersebut dapat ditangkap. Sedangkan untuk menyembuhkan tanaman dari penyakit yang mungkin muncul, petani mengidentifikasi terlebih dahulu lalu mengambil tindakan sesuai dengan tingkat keparahan penyakit pada tanaman. Jika sudah terlalu parah, maka jalan satu-satunya adalah menyulam dengan tanaman baru yang masih sehat.

Pada saat penelitian dilakukan petani memasuki musim kering untuk proses penanaman sampai panen, sehingga produktifitas lebih rendah dibandingkan dengan musim sebelumnya. Namun penurunan produktifitas tersebut bukan karena kesuburan tanah atau penggunaan pupuk yang kurang karena hanya mengandalkan pupuk organik. melainkan karena adanya hama seperti tikus, burung, dan keong mas yang memakan tanaman mulai dari awal proses tanam sampai menjelang panen. Hal ini jelas merugikan petani dan sangat mengurangi pendapatan karena hasil panen tidak sesuai dengan ekspektasi pada saat awal penanaman. Tapi ada juga yang mengalami kekeringan karena letak sawah yang sangat jauh dari sumber air dan saluran irigasi tidak berfungsi secara baik.

Sebagian petani mengeluh hasil panen mereka menurun sampai 50 persen dibandingkan dengan musim sebelumnya. terlebih lagi jika petani menerapkan sistem bagi hasil karena tidak memiliki lahan sendiri. Sistem bagi hasil yang diterapkan umumnya sebesar 40-60 dimana petani penggarap memperoleh sebesar 60 persen hasil dengan beban pengeluaran input oleh petani penggarap, sedangkan pemilik lahan mendapat 40 persen tanpa beban biaya input apapun. Ada juga yang menerapkan bagi hasil 50-50, dimana petani penggarap memperoleh 50 persen hasil dengan pembagian beban input untuk pupuk 50 persen dan benih 0 persen. Pemilik lahan menyediakan kebutuhan benih 100 persen dan pupuk sebanyak 50 persen dari total pupuk yang digunakan. Sedangkan beban kredit, diberikan kepada penggarap karena sepenuhnya menjadi tanggung jawab penggarap untuk mengolah lahan sampai menghasilkan produk berupa gabah kering panen yang langsung dijual pada saat panen supaya bisa melunasi kredit yang telah diambil pada 
saat awal musim tanam (bagi penerima kredit).

Rata-rata panen padi untuk penerima kredit adalah 4,77 ton dan petani bukan penerima kredit adalah 5,52 ton. Hasil panen ini tidak bisa disimpulkan bahwa petani bukan penerima kredit lebih produktif dibandingkan dengan petani penerima kredit. Petani penerima kredit pada saat musim panen yang lalu banyak mengalami kerugian karena banyak hama burung yang memakan malai padi yang sedang dalam proses pematangan bulir padi. Hal ini menjadikan hasil panen sangat menurun dan tidak bisa diatasi hanya dengan menggunakan orang-orangan sawah atau jaring perangkap, sedangkan jika menggunakan metode penangkapan secara massal, harus melibatkan petani lainnya agar lebih efektif prosesnya dan ini membutuhkan biaya lain di luar rencana usahatani yang telah disusun pada awal musim tanam.

\section{Penyaluran Kredit Mikro}

Petani padi organik di Kabupaten Bogor mengakses kredit untuk menutupi kekurangan modal dalam membiayai usahatani. Semakin luas lahan garapan, maka jumlah kredit yang diakses semakin besar. Besaran kredit yang bisa diakses oleh petani padi organik di Kabupaten Bogor antara 200 ribu sampai 2 juta rupiah. Lembaga yang diakses pun hanya sampai pada lembaga semi-formal yaitu koperasi dan gapoktan. Koperasi membuka akses kredit untuk modal usahatani menggunakan dana simpan pinjam sehingga petani anggota dapat memanfaatkan fasilitas tersebut selama menjadi anggota. Sedangkan gapoktan, dengan dana yang diperoleh dari berbagai instansi pemerintah (PUAP, bantuan teknis, dan sebagainya), dapat memfasilitasi kredit selama petani menjadi anggota kelompok tani. Dana tersebut adalah akumulasi dari yang diberikan kepada Gapoktan dan dikelola perputarannya salah satunya untuk memfasilitasi kredit mikro bagi petani.

Baik koperasi maupun gapoktan memiliki aturan sendiri dalam menyalurkan kredit kepada petani. Aturan tersebut terbagi dua yaitu syarat dan ketentuan yang harus dipenuhi oleh petani. Untuk koperasi syarat yang diberlakukan yaitu (1) telah menjadi anggota koperasi; (2) merupakan anggota kelompok tani; dan (3) tidak memiliki tunggakan kredit di musim tanam sebelumnya. Selain itu berlaku ketentuan : (1) pembayaran dilakukan setelah panen (tempo 4 bulan); (2) dikenakan biaya administrasi sebesar $1 \%$ per bulan; dan (3) hasil panen dijual ke koperasi. Ketentuan ini diberlakukan agar tidak terjadi moral hazard seperti tidak membayar tagihan kredit dan sebagainya yang dapat merugikan koperasi sebagai penyedia dana. Gambar 1 menunjukkan mekanisme kredit mikro yang disalurkan melalui koperasi dan gapoktan.

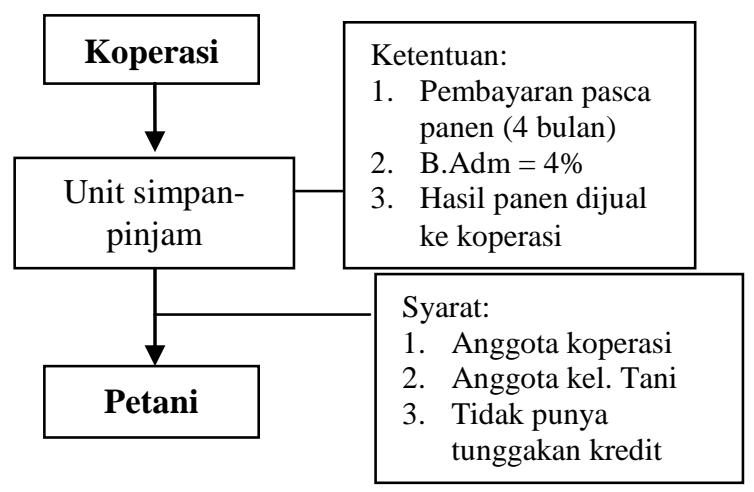

Gambar 1 Mekanisme penyaluran kredit mikro melalui koperasi

Untuk gapoktan, keuangan berasal dari hibah pemerintah daerah berupa dana bimbingan teknis yang dapat diatur penggunaannya oleh gapoktan dan semua anggotanya. Dana tersebut dikelola untuk memfasilitasi petani 
memperoleh tambahan modal karena tidak bisa meminjam ke lembaga semi formal lainnya. Gapoktan memberikan kredit secara langsung ke petani dengan

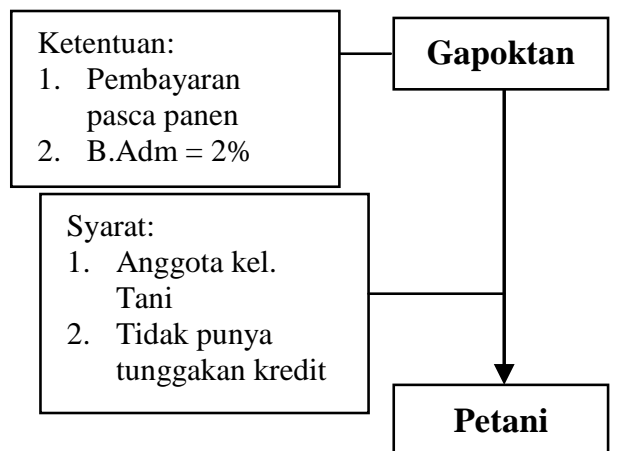

Gambar 2 Mekanisme penyaluran kredit mikro melalui gapoktan

Syarat yang diberlakukan adalah petani merupakan anggota kelompok tani yang menjadi anggota gapoktan dan tidak memiliki tunggakan kredit di musim sebelumnya. Adapun ketentuan yang harus dipenuhi oleh petani adalah biaya administrasi yang dibebankan sebesar $0,5 \%$ per bulan dan kredit tersebut dibayarkan pada saat panen $( \pm 4$ bulan) agar petani konsisten membayar kembali kredit yang telah diambil. Jika hasil panen tidak memberikan keuntungan, maka petani tetap harus membayar kredit tersebut dengan mencari sumber dana lainnya.Besaran kredit yang disalurkan ke petani beragam disesuaikan dengan luas lahan garapan. Semakin luas maka kredit yang diajukan dan dipenuhi semakin besar. Namun jumlah kredit yang diperoleh hanya untuk menambah modal usahatani yang akan dilakukan. Sedangkan modal usahatani secara keseluruhan menjadi tanggung jawab dari petani itu sendiri.

Ada juga petani yang memperoleh tambahan modal dari anggota keluarga sehingga dapat menambah modal usahatani sedangkan petani tersebut tidak dapat mengakses kredit atau kredit yang diperoleh tidak cukup membiayai syarat dan ketentuan yang telah disepakati bersama kelompok tani yang menjadi anggota gapoktan.

usahatani selama 1 musim tanam. Umumnya modal diperoleh dari hasil musim tanam sebelumnya dan juga modal dari sumber penghasilan lain bagi petani yang tidak menjadikan usahatani padi organik sebagai satusatunya mata pencaharian keluarga.

Tabel 5 Sumber modal usahatani responden berdasarkan luas lahan garapan

\begin{tabular}{cccc}
\hline $\begin{array}{c}\text { Luas } \\
\text { Lahan } \\
\text { (ha) }\end{array}$ & \multicolumn{2}{c}{$\begin{array}{c}\text { Sumber Kredit (Rp) dan } \\
\text { Jumlah Petani (\%) }\end{array}$} & $\begin{array}{c}\text { Modal } \\
\text { Sendiri }\end{array}$ \\
\cline { 2 - 3 } & Koperasi & Gapoktan & \\
\hline$<0,3$ & 491.000 & 500.000 & 872.000 \\
& $(\mathrm{n}=17,6 \%)$ & $(\mathrm{n}=4,4 \%)$ & $(\mathrm{n}=33,8)$ \\
$0,3-0,5$ & 741.600 & 1.000 .000 & $\begin{array}{c}2.428 .000 \\
(\mathrm{n}=8,8)\end{array}$ \\
& $\begin{array}{c}(\mathrm{n}=17,6 \%) \\
(\mathrm{n}=2,9 \%)\end{array}$ & $\begin{array}{c}\mathrm{n}=4.465 .000 \\
(\mathrm{n}=5,9)\end{array}$ \\
\hline $\begin{array}{c}1.750 .000 \\
(\mathrm{n}=5,9 \%)\end{array}$ & $\begin{array}{c}1.150 .000 \\
(\mathrm{n}=2,9 \%)\end{array}$ & \\
\hline $\begin{array}{c}\text { Jumlah } \\
\text { Petani } \\
(\%)\end{array}$ & 41,2 & 10,3 & 48,5 \\
\hline Sumber & : Data Primer &
\end{tabular}

Berdasarkan Tabel 4 dapat dilihat bahwa perbedaan luas lahan menentukan besaran kredit yang diterima oleh petani. Semakin luas lahan garapan, maka semakin tinggi biaya usahatani yang harus disiapkan begitu juga dengan nilai kredit yang diakses. Namun demikian petani yang memperoleh kredit juga tidak sepenuhnya mengandalkan kredit sebagai modal usahatani. Kredit mikro hanya diakses jika petani kekurangan modal dan alokasi penggunaannya tergantung dari kebutuhan petani pada saat itu. Jika sudah diakses, maka modal dari kredit langsung bercampur dengan modal sendiri yang dialokasikan untuk membeli input atau membayar tenaga kerja.

Berdasarkan tabel 5 dapat dilihat bahwa koperasi adalah lembaga yang 
paling banyak di akses oleh petani yaitu sebanyak 41,2 persens, sedangkan Gapoktan bisa diakses sebanyak 10,3 persen. Hal ini menandakan bahwa koperasi menjadi pilihan petani untuk memperoleh kredit mikro dan lebih dipercaya oleh petani. Selain itu, koperasi juga memberikan fasilitas lainnya di luar kegiatan usahatani. Selama petani menjadi anggota koperasi dan tertib mengikuti aturan, maka koperasi akan memberikan fasilitas yang dibutuhkan oleh petani termasuk juga kebutuhan rumahtangga petani.

Petani yang tidak mengakses kredit sepenuhnya menggunakan modal sendiri yang diperoleh dari pendapatan musim tanam sebelumnya. Petani ratarata melakukan kegiatan lain di luar aktivitas usahatani di lahan garapan sendiri. Sehingga jika terjadi gagal panen, petani masih memiliki cadangan pendapatan yang bisa digunakan untuk membiayai usahatani musim berikutnya.

\section{Analisis Akses Kredit Mikro pada Petani Padi organik}

Hasil analisis menggunakan Model Seleksi Heckman tahap pertama (model Probit) mengindikasikan bahwa terdapat 5 faktor yang dapat menentukan akses petani terhadap kredit mikro (Tabel 6). Hal ini sesuai dengan hipotesis dimana variabel usia, jumlah anggota keluarga, lamanya menjadi anggota kelompok tani, dan luas lahan garapan dapat menentukan peluang petani dalam mengakses kredit mikro, sedangkan variabel pendidikan petani tidak menentukan akses petani terhadap kredit mikro (tidak signifikan secara statistik).

Tabel 6 Aksesibilitas kredit mikro pada petani padi organik

\begin{tabular}{lllc}
\hline \multicolumn{1}{c}{ Variabel } & Koefisien & $\mathrm{Z}$ & $\mathrm{P}>|\mathrm{z}|$ \\
\hline Usia petani (tahun) & $-5,7813^{*}$ & -2.12 & 0.034 \\
Jumlah anggota keluarga (orang) & $-2.2103^{*}$ & -2.62 & 0.009 \\
Lama pendidikan petani (tahun) & -0.8045 & -0.56 & 0.573 \\
Pengalaman usahatani padi (tahun) & $-2.4997^{*}$ & -2.37 & 0.018 \\
Lama menjadi anggota kel. tani (tahun) & $5.3747^{*}$ & 3.21 & 0.001 \\
Luas lahan garapan $\left(\mathrm{m}^{2}\right)$ & $1.8641^{*}$ & 3.06 & 0.002 \\
Konstanta & 3.6258 & 0.84 & 0.404 \\
\hline LR chi & Prob $>\mathrm{chi}^{2}$ & $=0.0000$ \\
Log likelihood $=-31.57179$ & Pseudo $\mathrm{R}^{2}$ & $=0.3298$ \\
\hline
\end{tabular}

$\begin{array}{ll}\text { Sumber } & \text { : Data Primer (diolah) } \\ \text { Keterangan } & : \text { signifikan pada taraf nyata } 0,05\end{array}$

Secara komprehensif, semua variabel tersebut memiliki pengaruh terhadap peluang petani mengakses kredit mikro. Hal ini dibuktikan dengan nilai mutlak dari Log Likelihood yang lebih besar dari nilai $\mathrm{Z}$ tabel dan juga secara parsial melalui uji Wald menunjukkan nilai yang tinggi dengan probabilitas 0,000. Hal ini berarti bahwa secara parsial maupun bersama-sama, variabel dalam model telah dapat merepresentasikan nilai $\mathrm{Y}$ yaitu peluang akses atau tidak akses terhadap kredit mikro.

Usia memiliki koefisien negatif dan signifikan pada taraf nyata 0,05 Hal ini menunjukkan bahwa petani dengan usia tua cenderung bersifat risk averse (tidak mau mengambil risiko) sehingga keinginan untuk mengakses kredit juga kecil. Selain itu, petani dengan usia tua produktifitas kerja dianggap telah menurun sehingga dianggap tidak layak memperoleh kredit 
(credit worthiness rendah). Berbeda dengan petani muda yang masih berani mengambil risiko dalam mengembangkan usahataninya (risk taker) dan sangat berpeluang mengakses kredit (memiliki credit worthiness tinggi) karena produktifitas kerja masih tinggi. Hasil ini sejalan dengan temuan Oyedele et al 2009 dan Ibrahim dan Bauer (2013) menemukan bahwa semakin tua usia maka sikap petani cenderung tidak ingin mengambil risiko dan memilih mengandalkan modal yang dimiliki sendiri.

Jumlah anggota keluarga memiliki koefisien negatif, berarti jumlah anggota keluarga tidak menjamin kelayakan petani dalam mengakses kredit. Semakin banyak anggota keluarga, credit worthy petani semakin rendah. Walaupun ada anggota keluarga yang bekerja di sektor lain dan bisa menjamin pembayaran kredit. Namun lembaga kredit beranggapan kondisi tersebut merupakan sebuah keuntungan bagi petani sehingga modal usahatani sudah terjamin dan tidak perlu mengakses kredit. Hal ini sejalan dengan temuan Croppenstedt et al 2003, bahwa banyaknya anggota keluarga dapat menjamin ketersediaan modal, meningkatkan efisiensi penggunaan tenaga kerja, dan mengadopsi teknologi sehingga dapat meningkatkan produksi pertanian.

Lamanya seorang petani menjadi anggota kelompok tani dapat menentukan peluang dalam mengakses kredit mikro. Keikutsertaan petani dalam kelompok tani merupakan modal sosial (social capital) yang sangat membantu petani dalam memperoleh jaringan informasi dan melalui keaktifannya dalam kelompok, akan terlihat motivasi dan karakter petani dalam pengelolaan sumber daya yang dimiliki, termasuk modal (Yirga 2007) sehingga layak memperoleh kredit (Ibrahim dan Bauer 2013). Hal ini juga dapat mencegah terjadinya moral hazard karena semua anggota kelompok tani berada dalam pengawasan langsung ketua kelompok tani.

Luas lahan garapan juga menentukan peluang petani mengakses kredit mikro karena dapat dikatakan sebagai aset penting dalam kegiatan usahatani. Dimana setiap peningkatan luas lahan garapan membuka peluang petani untuk mengakses kredit karena ekspektasi akan meningkatnya produksi dan pendapatan usahatani. Lahan garapan yang lebih luas akan meningkatkan credit worthiness petani.. Hal yang sama juga ditemukan oleh Ibrahim dan Bauer (2013), dimana kepemilikan lahan menentukan keputusan untuk mengakses kredit untuk menambah biaya operasional dan harapan hasil panen yang lebih banyak akan memudahkan dalam pengembalian kredit pada saat panen nanti.

\section{Dampak Kredit Mikro terhadap Produksi Padi organik}

Analisis dampak kredit mikro terhadap produksi padi organik dilakukan menggunakan model seleksi Heckman dua tahap, dimana hasil regresi probit tahap pertama mengindikasikan aksesibilitas kredit mikro yang telah dijelaskan sebelumnya. Pada tahap kedua dari Model Seleksi Heckman ini akan dibahas mengenai dampak kredit mikro terhadap produksi padi organik dan juga untuk membuktikan bahwa kredit mikro dapat berdampak positif terhadap produksi pagi organik. Sampel yang diikutsertakan dalam penghitungan dampak ini hanya adalah keseluruhan sampel dalam penelitian karena model ini dapat mengakomodasi penggunaan data tersebut. 
Tabel 7 Hasil analisis dampak kredit mikro terhadap produksi padi organik

\begin{tabular}{|c|c|c|c|}
\hline Variabel & Koefisien & $\mathrm{Z}$ & $\mathrm{P}>|\mathrm{z}|$ \\
\hline \multicolumn{4}{|l|}{ PRODUKSI PADI ORGANIK (outcome equation) } \\
\hline Jumlah penggunaan benih $(\mathrm{Kg})$ & $0,3341 *$ & 3,22 & 0,001 \\
\hline Jumlah penggunaan pupuk organik (kuintal) & $-0,0471$ & $-0,49$ & 0,627 \\
\hline Jumlah penggunaan pupuk kimia $(\mathrm{Kg})$ & $-0,0260$ & $-0,38$ & 0,704 \\
\hline Jumlah penggunaan tenaga kerja (HKP) & $0,7179 *$ & 4,03 & 0,000 \\
\hline Jumlah kredit (000 Rp) & $0,2457 *$ & 2,54 & 0,011 \\
\hline Konstanta & 0,3855 & 0,87 & 0,383 \\
\hline \multicolumn{4}{|l|}{ AKSES (selection equation) } \\
\hline Usia petani (tahun) & $-5,7813 *$ & $-2,12$ & 0,034 \\
\hline Jumlah anggota keluarga (orang) & $-2,2103 *$ & $-2,62$ & 0,009 \\
\hline Lama pendidikan petani (tahun) & $-0,8045$ & $-0,56$ & 0,573 \\
\hline Pengalaman usahatani padi (tahun) & $-2,4997 *$ & $-2,37$ & 0,018 \\
\hline Lama menjadi anggota kel. tani (tahun) & $5,3747^{*}$ & 3,21 & 0,001 \\
\hline Luas lahan garapan $\left(\mathrm{m}^{2}\right)$ & $1,8641 *$ & 3,06 & 0,002 \\
\hline Konstanta & 3,6258 & 0,84 & 0,404 \\
\hline \multicolumn{4}{|l|}{ RASIO MILLS } \\
\hline Lambda & 0,03604 & 1,12 & 0,261 \\
\hline Rho & 0,54285 & & \\
\hline Sigma & 0,06639 & & \\
\hline Wald chi2(5) $=493.38$ & Prob > chi 2 & 0.0000 & \\
\hline $\begin{array}{ll}\text { Sumber } & : \text { Data Primer } \\
\text { Keterangan } & : * \text { signifikan pada taraf nyata } 0,05\end{array}$ & & & \\
\hline
\end{tabular}

Secara komprehensif, analisis regresi probit yang merupakan tahap pertama dari model seleksi Heckman dilakukan dengan bantuan perangkat lunak STATA 13.0 dengan memasukkan semua variabel penjelas ke dalam model. Pengujian parameter secara simultas dengan uji $\mathrm{G}$ didapatkan nilai statistik Wald Chi-square sebesar 493,38 dengan nilai prob $>\mathrm{chi}^{2}=0,0000$ ( $\mathrm{p}<0,05)$. Jika $\mathrm{H}_{0}=$ variabel bebas tidak berpengaruh nyata terhadap variabel tak bebas dan $\mathrm{H}_{1}=$ variabel penjelas berpengaruh nyata terhadap variabel tak bebas, dikarenakan $0,0000<0,05$ maka disimpulkan bahwa $\mathrm{H}_{0}$ ditolak. Artinya setidaknya ada satu variabel bebas yang berpengaruh nyata terhadap produksi padi organik. Pengujian parameter secara parsial dilakukan dengan uji Wald, variabel yang berpengaruh nyata pada taraf nyata 0,05 adalah jumlah penggunaan benih, jumlah tenaga kerja, dan jumlah kredit seperti yang terlihat pada Tabel 7.

Jumlah penggunaan benih secara statistika memiliki dampak positif dan signifikan pada taraf 0,05 . Hal ini menunjukkan bahwa peningkatan penggunaan benih akan meningkatkan produksi padi organik. Walau begitu, kembali pada jenis benih yang digunakan oleh petani, karena ada beberapa varietas benih yang dapat menghasilkan banyak tanaman hanya dengan 1 butir benih saja seperti varietas situ bagendit. Tapi hanya beberapa petani yang menggunakan varietas tersebut sehingga masih membutuhkan banyak benih untuk ditanam agar menghasilkan tanaman yang banyak.

Variabel lain yang signifikan adalah penggunaan tenaga kerja. Semakin banyak menggunakan tenaga kerja, hasil produksi padi organik akan 
meningkat. Tanda pada koefisien bernilai positif dan signifikan pada taraf 0,05 . Hal ini menunjukkan bahwa semakin banyak penggunaan tenaga kerja akan meningkatkan produksi padi organik. Pada pembahasan sebelumnya mengenai input dan output produksi padi organik telah dijelaskan bahwa perbandingan penggunaan tenaga kerja wanita, pria, dan mesin tidak sama. Diduga bahwa peningkatan salah satunya akan meningkatkan produksi padi organik, yaitu tenaga kerja mesin. Temuan yang sama didapatkan oleh Nuryartono et al (2005) bahwa penggunaan tenaga kerja dapat meningkatkan pendapatan yang mana berasal dari hasil produksi yang lebih tinggi sehingga penerimaan meningkat.

Pada penelitian ini, penggunaan tenaga kerja manusia digabungkan dengan tenaga kerja mesin yang dikonversi ke dalam tenaga kerja pria. Seperti yang ditemukan oleh Zeller et al 1997, bahwa kredit berpengaruh nyata karena dapat meningkatkan kemampuan petani untuk memperoleh sarana produksi pertanian yang lebih modern. Salah satunya adalah mesin (traktor). Dengan demikian produksi padi dapat ditingkatkan.

Variabel penting yang mempengaruhi produksi adalah kredit mikro. Kredit memiliki koefisien positif dan signifikan para taraf nyata 0,05 , maka dapat dikatakan bahwa kredit memberikan dampak positif terhadap peningkatan produki padi organik. Semakin tinggi jumlah kredit, maka semakin tinggi produksi padi organik. Hal ini dikarenakan dengan adanya kredit, petani dapat mengadopsi teknologi yang dapat meningkatkan produktifitas padi. Sejalan dengan hasil penelitian Nuryartono (2004) bahwa tambahan modal dapat meningkatkan adopsi teknoogi untuk peningkatan produksi pertanian. Hal yang sama juga ditemukan oleh Crepon et al (2011), bahwa kredit dapat meningkatkan skala usaha rumah tangga karena dapat membeli input produksi yang lebih baik dan dapat menghasilkan output lebih banyak.

\section{KESIMPULAN}

Berdasarkan hasil penelitian dapat disimpulkan hal-hal sebagai berikut:

1. Akses kredit mikro pada petani padi organik ditentukan secara negatif oleh faktor usia, jumlah anggota keluarga, dan pengalaman usahatani dan secara positif ditentukan oleh lamanya keanggotaan dalam kelompok tani dan luas lahan garapan. Lembaga kredit yang bisa diakses hanya lembaga semi-formal yaitu koperasi dan Gapoktan. Jumlah petani yang bisa mengakses kredit dari kedua lembaga tersebut sebanyak 51,5\% dari total responden dan digunakan sebesar 32,69 persen relatif terhadap total biaya usahatani.

2. Produksi padi organik ditentukan secara positif oleh jumlah benih, jumlah kredit, dan penggunaan tenaga kerja. Kredit terbukti mempengaruhi produksi padi organik karena dapat meningkatkan adopsi teknologi sehingga produksi dapat ditingkatkan.

\section{DAFTAR PUSTAKA}

Anggreani L. 2009 The Function of Social Networks for Informal Credits in Remote Rural Areas in Indonesia. Disertasi. The University of Tokyo. Tokyo.

Azriani Z. 2014. Aksesibilitas dan Partisipasi Industri Kecil dan Rumahtangga pada Sumber Pembiayaan dan Pengaruhnya terhadap Kinerja Usaha dan 
Kesejahteraan Rumahtangga di Kabupaten Bogor, Jawa Barat. Disertasi. Institut Pertanian Bogor, Bogor.

Badan Pusat Statistik Kabupaten Bogor. 2013. Jumlah Penduduk Miskin tahun 2012.

Badan Pusat Statistik Provinsi Jawa Barat. 2013. Berita Resmi Statistik : Pertumbuhan Ekonomi Jawa Barat Triwulan I-2013.

Bank Indonesia. 2013. Statistik Perbankan Indonesia. Vol : 11 No. 10. September 2013.

Badan Supervisi Bank Indonesia (BSBI). 2013. Kondisi Ekonomi Indonesia dan Peranan Bank Indonesia dalam Pembangunan Daerah.

Crepon B F. Devoto, E. Duflo, dan W. Pariente. 2011. Impact of Microcredit in Rural Areas of Morocco : Evidence from Randomizes Evaluation. Working Paper.

Croppenstedt A, Demake M, Meschi MM. 2003. Technology Adoption in The Presence of Constraints : The Case of Fertilizer Demand in Ethiopia. Rev. of Development Economic 7 (1) : 58-70.

Ditjen BP2HP Kementerian Pertanian RI. 2010.

Gultom L. 2014. Analisis Efisiensi Teknis Usahatani Padi Semi Organik di Kecamatan Cigombong Kabupaten Bogor. Tesis. Institut Pertanian Bogor, Bogor

Hanafie R. 2010. Pengantar Ekonomi Pertanian. Penerbit Andi. Yogyakarta.

Heckman J J. 1976. The Common Structure of Statistical Models of Truncation, Sample Selection and Limited Dependent Variables and A simple Estimator for such Models. Annals of Economic and
Social Measurement. 5 (1) : 475492.

Hopkins D. 2005. Heckman Selection Models. Bahan Ajar.

Ibrahim A L H dan Bauer, S. 2013. Access to Micro credit and its Impact on Farm Profit Among Rural Farmers in Dryland of Sudan. Global Advanced Research Journal of Agricultural Science 2 (3) : 88-102.

Kusmuljono BS, Eriyatno, B Sanim, dan G Sumodiningrat. 2007. Sistem Pengembangan Usaha Pertanian Berbasis Lingkungan Didukung Lembaga Keuangan Mikro. Jurnal Forum Pascasarjana 30 (1) : 49-59.

Nizar R. 2004. Analisis Permintaan dan Pengembalian Kredit Usahatani oleh Rumahtangga Petani Padi di Sumatera Barat. Tesis. Institut Pertanian Bogor, Bogor

Nuryartono N. 2004. Smallholders Access to Credit and its Impact on the Adoption of Agricultural Technology: Evidence and Lesson from Agriculture Practices in the Vicinity of Lore Lindu National Park, Central Sulawesi, Indonesia Makalah. Tropentag, Gottingen

Oyedele GA, Akintola JO, Rahji MAY, dan Omonona BT. 2009. Credit Constrained Condition of Farm Households and Profitability of Agricultural Production in Nigeria Agriculture. Agricultural Journal 4 (4) : 192-201.

Paloma C. 2013. Adverse Selection dan Moral Hazard pada Skim Kredit Lembaga Keuangan Mikro Agribisnis (LKM-A) PUAP di Kota Padang. Tesis. Institut Pertanian Bogor, Bogor

Rahayu RB. 2011. Preferensi Risiko Petani pada Usahatani Padi organik di Kabupaten Bogor. 
Tesis. Institut Pertanian Bogor, Bogor

Saragih SE. 2010. Pertanian Organik : Solusi Hidup Harmoni dan Berkelanjutan. Penebar Swadaya. Jakarta

Yirga CT. 2007. The Dinamic of Soil Degradation and Incentives for Optimal Management in Central Highlandss of Ethiopia. Disertasi.
University of Pretoria. Afrika Selatan

Zeller, M., G Schrieder, J von Braun, F Heidhues. 1997. Rural Finance for Food Security for The Poor : Implications for research and Policy. Dalam : Food Policy Review (4). International Food Policy Research Intitute, Washington DC. 
Lampiran 1 Hasil statistik deskriptif variabel yang dibedakan berdasarkan akses kredit dengan menggunakan program STATA 13.0

by AKSES, sort : summarize USIA JAKL PDKN PGLM AGTKL LLHN JBNH PORG PKIM JHKP KREDIT PGKP PRFT PRDTF, separator(0) $\rightarrow$ AKSES $=0$

\begin{tabular}{|c|c|c|c|c|c|}
\hline Variable & Obs & Mean & Std. Dev. & Min & Max \\
\hline USIA & 33 & 54.15152 & 10.49441 & 33 & 71 \\
\hline JAKL & 33 & 3.575758 & 2.411305 & 1 & 11 \\
\hline PDKN & 33 & 8.363636 & 2.690471 & 5 & 16 \\
\hline PGLM & 33 & 18.15152 & 8.518807 & 5 & 36 \\
\hline AGTKL & 33 & 6.939394 & 2.474108 & 2 & 10 \\
\hline LLHN & 33 & 2575.758 & 2278.024 & 500 & 10000 \\
\hline JBNH & 33 & 8.121212 & 5.844375 & 1 & 25 \\
\hline PORG & 33 & 2001.667 & 1737.351 & 300 & 7500 \\
\hline PKIM & 33 & 24.54545 & 20.00483 & 5 & 110 \\
\hline JHKP & 33 & 37.60606 & 26.33906 & 9 & 118 \\
\hline KREDIT & 33 & 0 & 0 & 0 & 0 \\
\hline PGKP & 33 & 1583.333 & 1641.677 & 200 & 7000 \\
\hline PRDTF & 33 & 5.578788 & 1.344377 & 2.7 & 8.2 \\
\hline \multicolumn{6}{|c|}{$\rightarrow \mathrm{AKSES}=1$} \\
\hline Variable & Obs & Mean & Std. Dev. & Min & Max \\
\hline USIA & 35 & 51.25714 & 11.9468 & 30 & 73 \\
\hline JAKL & 35 & 2.685714 & 1.745101 & 0 & 9 \\
\hline PDKN & 35 & 8.257143 & 2.638436 & 6 & 16 \\
\hline PGLM & 35 & 16 & 10.53845 & 3 & 50 \\
\hline AGTKL & 35 & 7.6 & 2.185514 & 3 & 10 \\
\hline LLHN & 35 & 3800 & 2364.567 & 1000 & 10000 \\
\hline JBNH & 35 & 10.8 & 5.890171 & 3 & 25 \\
\hline PORG & 35 & 2302.857 & 1542.388 & 500 & 7000 \\
\hline PKIM & 35 & 26.25714 & 13.03918 & 5 & 64 \\
\hline JHKP & 35 & 55.94286 & 29.16983 & 20 & 158 \\
\hline KREDIT & 35 & 778571.4 & 430336 & 200000 & 2000000 \\
\hline PGKP & 35 & 1855.429 & 1194.771 & 550 & 5800 \\
\hline PRDTF & 35 & 5.044857 & 1.275148 & 2.6 & 9 \\
\hline
\end{tabular}

Lampiran 2 Hasil Pengolahan model Seleksi Heckman 2 tahap untuk akses dan dampak kredit mikro terhadap produksi padi organik dengan menggunakan program STATA 13.0

heckman LogPGKP LogJBNH LogPORG LogPKIM LogJHKP LogKREDIT, twostep select(AKSES = LogUSIA LogJAKL LogPDKN LogPGLM LogAGTKL LogLLHN) rhosigma first

Iteration 0: $\log$ likelihood $=-47.104592$

Iteration 1: $\log$ likelihood $=-32.413424$

Iteration 2: $\log$ likelihood $=-31.58823$

Probit regression
Iteration 3: $\log$ likelihood $=-31.5718$

Iteration 4: $\log$ likelihood $=-31.57179$

$$
\begin{array}{ll}
\text { Number of obs } & =68 \\
\text { LR chi2(6) } & =31.07 \\
\text { Prob }>\text { chi } 2 & =0.0000
\end{array}
$$




\begin{tabular}{|c|c|c|c|c|c|c|}
\hline \multicolumn{3}{|c|}{ Log likelihood $=-31.57179$} & \multicolumn{2}{|c|}{ Pseudo R2 } & \multicolumn{2}{|c|}{$=0.3298$} \\
\hline AKSES & Coef. & Std. Err. & $\mathrm{z}$ & $\mathrm{P}>|\mathrm{z}|$ & \multicolumn{2}{|c|}{ [95\% Conf. Interval] } \\
\hline LogUSIA & -5.781293 & 2.723998 & -2.12 & 0.034 & -11.12023 & -0.442356 \\
\hline LogJAKL & -2.210329 & 0.842296 & -2.62 & 0.009 & -3.861198 & -0.559460 \\
\hline LogPDKN & -0.804546 & 0.427434 & -0.56 & 0.573 & -3.602266 & 1.993173 \\
\hline LogPGLM & -2.499723 & 0.054961 & -2.37 & 0.018 & -4.567408 & -0.432038 \\
\hline LogAGTKL & 5.374647 & 1.674633 & 3.21 & 0.001 & 2.092427 & 8.656867 \\
\hline LogLLHN & 1.864059 & .6101264 & 3.06 & 0.002 & 0.668233 & 3.059884 \\
\hline _cons & 3.625764 & 4.340357 & 0.84 & 0.404 & -4.881180 & 12.132710 \\
\hline \multirow{5}{*}{\multicolumn{4}{|c|}{$\begin{array}{l}\text { Heckman selection model -- two-step estimates } \\
\text { (regression model with sample selection) }\end{array}$}} & \multicolumn{3}{|c|}{ Number of obs $=68$} \\
\hline & & & & \multicolumn{3}{|c|}{ Censored obs $=33$} \\
\hline & & & & \multicolumn{2}{|c|}{ Uncensored obs } & \\
\hline & & & & \multicolumn{2}{|c|}{ Wald chi2(5) } & 493.38 \\
\hline & & & & \multicolumn{2}{|c|}{ Prob > chi 2} & 0.0000 \\
\hline & Coef. & Std. Err. & $\mathrm{Z}$ & $\mathrm{P}>|\mathrm{z}|$ & {$[95 \%$ Con } & Interval] \\
\hline \multicolumn{7}{|l|}{ LogPGKP } \\
\hline LogJBNH & 0.334098 & 0.103893 & 3.22 & 0.001 & 0.130472 & 0.537724 \\
\hline LogPORG & -0.047068 & 0.096768 & -0.49 & 0.627 & -0.236731 & 0.142594 \\
\hline LogPKIM & -0.026005 & 0.068402 & -0.38 & 0.704 & -0.160071 & 0.108060 \\
\hline LogJHKP & 0.717988 & 0.178078 & 4.03 & 0.000 & 0.368961 & 1.067016 \\
\hline \multirow{2}{*}{$\begin{array}{l}\text { LogKREDIT } \\
\text { cons }\end{array}$} & 0.245725 & 0.096583 & 2.54 & 0.011 & 0.056426 & 0.435023 \\
\hline & 0.385515 & 0.442325 & 0.87 & 0.383 & -0.481427 & 1.252457 \\
\hline \multicolumn{7}{|l|}{ AKSES } \\
\hline LogUSIA & -5.781293 & 2.723998 & -2.12 & 0.034 & -11.12023 & -0.442356 \\
\hline LogJAKL & -2.210329 & 0.842296 & -2.62 & 0.009 & -3.861198 & -0.559460 \\
\hline LogPDKN & -0.804546 & 0.427434 & -0.56 & 0.573 & -3.602266 & 1.993173 \\
\hline LogPGLM & -2.499723 & 0.054961 & -2.37 & 0.018 & -4.567408 & -0.432038 \\
\hline LogAGTKL & 5.374647 & 1.674633 & 3.21 & 0.001 & 2.092427 & 8.656867 \\
\hline \multirow{2}{*}{ LogLLHN } & 1.864059 & 6101264 & 3.06 & 0.002 & 0.668233 & 3.059884 \\
\hline & 3.625764 & 4.340357 & 0.84 & 0.404 & -4.881180 & 12.132710 \\
\hline \multicolumn{7}{|l|}{ Mills Ratio } \\
\hline lambda & 0.0360416 & 0.032077 & 1.12 & 0.261 & -0.0268281 & 0.0989113 \\
\hline rho & 0.5428500 & & & & & \\
\hline sigma & 0.0663929 & & & & & \\
\hline
\end{tabular}

